\title{
Neoplastic Cells with TFH Cell Phenotype Present
}

National Cancer Institute

\section{Source}

National Cancer Institute. Neoplastic Cells with TFH Cell Phenotype Present. NCI

Thesaurus. Code C139010.

An immunohistochemical finding indicating the presence of neoplastic lymphocytes

manifesting a $\mathrm{T}$ follicular helper ( $\mathrm{TFH}$ ) phenotype. 